\title{
Etiese vrae oor en perspektiewe op die mediese beëindiging van die lewe
}

\author{
Prof Laetus O K Lategan \\ Technikon Vrystaat, Bloemfontein
}

Has anyone the right to pull the plug? - Lord Smith.

Moeder, ik was onschuldig en toch ben ik vermoord (Van Straelen 1972:32).

\begin{abstract}
Ethical questions and perspectives on the medical ending of life

A thorny issue in medical ethics is the medical ending of life. This article looks into the phenomena of abortion and euthanasia as examples of the medical ending of life. For the purposes of this article attention is paid to the theological criteria for abortion and euthanasia. Medical examples are then provided which illustrate the ethical difficulty in dealing with situations in which one has to make a decision whether a life should be medically ended or not. The article concludes with pastoral perspectives on dealing with the issues of abortion and euthanasia.
\end{abstract}

\section{AKTUALITEIT VAN DIE TEMA}

'n Kinderlose egpaar se laaste hoop op 'n kind van hulle eie is deur middel van in vitro bevrugting. As gelowiges worstel hulle met die vraag in hoe verre mag eksperimenteel met menslike lewe omgegaan word? Die probleem word op die spits gedryf deur die gebruik van donorsaad en die oorskot embrio's wat nie ingeplant gaan word nie. Hulle wonder of dit eties korrek is dat potensiële lewe vernietig word? Die geneesheer weer wonder of hy of sy die waarheid aan hulle moet meedeel naamlik dat op die oorblywende embrio's geëksperimenteer gaan word? Mag lewe as "navorsingsmateriaal" gebruik 
word? Na drie maande van swangerskap blyk dit om mediese redes dat 'n terapeutiese aborsie aangevra sal moet word. Mag ontwikkelende lewe vernietig word? Net in die volgende saal is die egpaar se moeder onherstelbaar komatieus. Die familie worstel met die vraag of die ontkoppeling van die asemhalingsondersteunende apparaat nie dalk oorweeg moet word nie? Is genadedood nie 'n kontra vir lewensontluistering nie? Mag kwynende lewe vernietig word?

In hierdie artikel word aandag gegee aan etiese probleme wat kan ontstaan wanneer lewe deur mediese ingrepe beëindig kan word. Om die botsing van pligte binne hierdie konteks te begryp, is dit noodsaaklik om eers aandag aan die bedoeling van die sesde gebod te gee, die vraag oor die ontstaan en einde van die lewe en wanneer mediese ingrepe in die beëindiging van lewe eties regverdig kan word. Hierna sal pastoraal-etiese riglyne vir die grenssituasies aangelê word.

\section{DIE BEDOELING VAN DIE SESDE GEBOD}

Die Biblia Hebraica Stuttgartensia-teks van Eksodus 20:13 lui "Jy mag nie wederregtelik doodmaak nie". Die Hebreeuse werkwoord "rasah" (wat slegs 67 keer in die Ou Testament voorkom) wat hier gebruik word, het betrekking op doodmaak met voorbedagte rade. Hoewel "rasah" byvoorbeeld in Deuternomium 4:41-43; 19:1-13 en Josua 20:21 gebruik word vir nie-opsetiike doodmaak, het nadere ondersoek aan die lig gebring dat "rasah" betrekking het op opsetlike doodslag. Vir die dood op juridiese gronde of in oorlog word "harag" en "naka" gebruik. Alle doding word egter nie deur die sesde gebod verbied nie - slegs die wederregtelike (onwettige) en daarom onbevoegde doodmaak van 'n mens sonder dat die Here so 'n opdrag gee. Dit gaan dus hier om dood as moord en nie as straf op onskuldige bloedvergieting nie.

Die sesde gebod handel eksklusief oor die beskerming van die beelddraer van God (Velema 1983:26) hoewel dit nie ander vorme van lewe uitsluit nie (Douma 1986: 133-146). Wie 'n mens (ook hom/haarself) doodmaak, tas die beeld van God aan. God is die Gewer van lewe. Gevolglik mag lewe nie verabsoluteer word nie - dit wil sê letterlik van God losgemaak en tot afgod verhef word nie. Nog minder mag dit geminimaliseer 
word - dit wil sê, ook losgemaak word van God en dan prakties tot niks of baie min verlaag word (Heyns 1982:329-331).

Die bedoeling van die gebod is nie net 'n verbod op doodmaak (Gen 9:6) nie, maar ook 'n verbod op vloek (Jakobus 3:9) omdat 'n mens na die beeld van God geskape is. Daarom kan die naaste onteer word sonder dat iemand sy of haar vinger verroer (1 Samuel 25:10; 2 Samuel 16-17). In die sesde gebod gaan dit daarom dat die naaste nie met gedagte, woorde, gebare of dade benadeel of doodgemaak mag word nie. Niemand mag ook wraakgierig wees nie en 'n mens mag jouself ook nie onnodig in gevaar stel nie (Die Heidelbergse Kategismus Sondag 40). Die radikaliteit van hierdie gebod is dat dit enige verkeerde gesindheid van die religieuse hart teenoor lewe afwys (Douma 1986:163167).

Die beskerming van lewe kan maklik ontaard in 'n oordrewe klem op lewe indien die behoud daarvan ten alle koste moet wees. Dikwels word gemeen dat eerbied vir die lewe beteken om lewe ten alle koste te behou. Noodwendig moet dit lei tot die onnodige uitrekking van lewe en effektief die verlenging van lyding. Wie eerbied vir die lewe so interpreteer, word deur ' $n$ vitalistiese beskouing gevange geneem. Die mens wie se lewe in diens van God is, vind 'n vitalistiese beskouing van die lewe onaanvaarbaar (Smit 1985:200). Sodanige lewensingesteldheid druis teen die Bybelse bedoeling van lewe in.

Die probleem hier is nie die beskerming van die lewe nie, maar die aksent op die lewe van die mens in plaas van God wat die Gewer van die lewe is. Lewe word as geabstraheerde biotiese objek los van die mens as beelddraer van God gemaak. Dit is een ding om lewe as objek te koester tot die einde toe en 'n ander om dit as 'n subjek (volledige persoon) te beskerm omdat God die Gewer van die lewe is.

Die gebruik van die sesde gebod in die mediese etiek kan 'n mens van bostaande probleme vrywaar. Die volgende riglyne kan as belangrik beskou word:

- God as die Gewer van die lewe, skep die mens na God se beeld en gebied dat lewe eerbiedig sal word.

- Die gebod verbied implisiet die neem van ontwikkelende en kwynende lewe. Alle menslike lewe dra die beeld van God - ongeag die lewenskwaliteit daarvan. 
- Lewe is ' $n$ genadegawe van God en daarom is dit 'n voorreg om te lewe. Omdat God uit genade 'n lewe aan 'n mens skenk, het 'n mens die reg om te lewe. Hierdie reg behoort nie net deur die owerheid beskerm te word nie, maar word deur God self beskerm as God in die sesde gebod die wederregtelike doodmaak van die mens verbied. Om te lewe, is sowel 'n voorreg as 'n reg.

- Lewe mag nie in abstracto eerbiedig word nie, maar moet as 'n geïntegreerde deel van 'n persoon subjektief beskerm en eerbiedig word. Soos eerbied vir die lewe afneem, neem die huiwering vir die dood ook af. Eerbied vir die lewe is nie 'n behoud daarvan ten alle koste nie. Wie dit doen, het lyding se regmatige plek ontneem. Wie geen ruimte laat vir lyding nie, is nie minder skuldig nie. Tussen sinvolle lyding en die onafwendbaarheid daarvan moet 'n balans wees. Op hierdie opmerking word weer in paragraaf 8 teruggekom.

\section{DIE BEGIN VAN LEWE}

Daar is verskillende standpunte wat die kriteria vir die begin van lewe wil vaslê: Inplanting, die primitiewe strook, breinfunksie of waarnemingsvermoë, fetale beweging, animasie, lewensvatbaarheid, ensovoorts.

Dit is egter eties ontoelaatbaar dat 'n wig tussen liggaamlikheid en persoonwees ingedryf word. Dit misken die waarde wat elke beelddraer van God van die begin af het. Die Gereformeerde etiek se standpunt dat die oomblik van bevrugting as die begin van lewe beskou moet word, word as 'n a priori in hierdie studie beskou. Die beskikbare Skrifgegewens (Job 10:8-12; Psalm 139:13-6) in verband met die ontstaan van lewe laat geen ruimte vir die onderskeiding wat getref word tussen 'n nog-nie-mens-fase en 'n daaropvolgende mens-fase in die voorgeboortelike ontwikkeling nie. 'n Vrug is vanaf bevrugting beeld van God. Vanweë die genetiese verbinding van die sperm/eiersel moet gesê word dat dit 'n eenmalige, unieke en nuwe menslike lewe is. Wie hierdie lewe afsny, beëindig nie maar net 'n potensiaal nie, maar beroof dit van die unieke menslike lewe wat dit alreeds is. Gevolglik is ook die fetus vanaf die moment van bevrugting geregtig op dieselfde beskerming en sorg wat die mens nageboortelik kan opeis (Du Toit 1978:95-96; 1989:108-109; Smit 1985:176). 
Vir die doeleindes van hierdie artikel kan die volgende standpunte ten opsigte van voorgeboortelike lewe gehandhaaf word:

- 'n Sigoot is 'n mens.

- $\quad$ 'n Sigoot bestaan uit, deur en tot God.

- 'n Sigoot is geskape na die beeld van God en daarom is dit ' $n$ beelddraer van God deur al die stadia van die lewe heen.

- 'n Sigoot het die reg op 'n mens se respek, liefde, billikheid en medemenslikheid.

- Die Bybel verwys met 'n eerbied na 'n fetus wat lynreg indruis teen die teenswoordige veragting van voorgeboortelike lewe.

\section{DIE OOMBLIK VAN BIOTIESE DOOD}

Biotiese dood het te doen met die doodgaan van die liggaam. Hier kom breindood, orgaandood, spierdood en sellulêre dood ter sprake. Die kriteria vir biotiese dood word deur die sogenaamde beginsel van breindood bepaal. Die Harvard-kriteria omskryf die grens tussen lewe en dood - dus breinddood - na aanleiding van die vordering op die gebied van die mediese tegnologie soos volg:

- Afwesigheid van diep reflekse.

- Geen willekeurige beweging nie.

- Geen spontane asemhaling nie.

- Geen breinaktiwiteit nie (Verny 1984:148).

Volgens hierdie kriteria het biotiese dood ingetree. Opnames van die breinfunksie word deur middel van EEG (opnames van die elektriese aktiwiteit van die brein); gammaënkefalograaf (registreer aanwesigheid of afwesigheid van isotope en dus bloedsirkulasie oor die brein) en arterograaf (registreer ook die moontlike aanwesigheid van breinaktiwiteit deur kleurstof wat in die bloed gesirkuleer word) geneem. 


\section{ETIES-AANVAARBARE REDES VIR ABORSIE}

In die Suid-Afrikaanse gemeenskap is aborsie op aanvraag beskikbaar. Vrye aborsie word egter eties veroordeel omdat dit 'n ontwikkelende mens (kyk paragraaf 3) wederregtelik van sy of haar lewe beroof. Hoewel die etiek nooit vrede kan hê met die wederregtelike neem van 'n lewe nie, kan dit ook nie na grenssituasies deur 'n donkerbril kyk nie. In 'n gebroke wêreld duik onafwendbare situasies op waartydens dit nie anders kan as om 'n lewe wederregtelik te neem nie. Hiervoor moet eties aanvaarbare indikasies gevind word vir sodanige situasies. As moontlike eties aanvaarbare indikasies kan die volgende gelys word:

- Waar die voortgesette swangerskap 'n bedreiging inhou vir die lewe van die vrou.

- Waar die swangerskap 'n ernstige bedreiging inhou vir haar liggaamlike gesondheid.

- Waar die swangerskap 'n ernstige bedreiging inhou vir die vrou se geestesgesondheid.

- Waar daar 'n gevaar bestaan dat die kind aan 'n liggaamlike- of geestesgebrek van so ' $n$ aard ly dat die kind onherstelbaar emstig gestrem sal wees.

- Waar die vrug uit bloedskande of verkragting verwek is.

- Waar die swangerskap die resultaat is van onwettige gemeenskap met ' $n$ vroulike idioot of swaksinnige.

Die mediese maatstaf vir aborsie behoort te wees of die voortsetting van swangerskap sal lei tot die moeder se dood of permanente verlies van gesondheid (Smit 1985: 187). Lewe en gesondheid mag nie op een lyn gestel word nie. Dit is "normaal" dat vrouens tydens swangerskap siek is maar hierdie ongesteldheid bedreig nie noodwen-dig hulle of die kind se lewe nie (Du Toit 1978:103).

'n Indikasie dui nie op 'n toelaatbaarheid wat andersins nooit toelaatbaar is nie. Dit is ' $n$ indikasie van die mens se onvermoë om beide lewens te red. Gevolglik kom 'n onafwendbare keuse hier ter sprake. Eties gesien, word ' $n$ indikasie ingespan in 'n by- 
kans onmoontlike dilemma waaruit die mens alleen kan kom met skuld en pyn omdat 'n onskuldige mens se lewe geneem moes word.

\section{KRITERIA VIR GENADEDOOD}

Soos reeds gesê, is biotiese dood die kriterium vir genadedood (paragraaaf 4). Hoewel hierdie kriterium belangrik is, word dit nóg in passiewe (ontrekking van alle behandeling gerig op die herstel van lewe) nóg in aktiewe genadedood (mediese ingrepe om lewe te beëindig) as enigste kriterium gehandhaaf.

Voorstaanders van aktiewe genadedood sê dat elke mens die reg het om self oor sy of haar lewe te beskik (Van Vuuren \& Vorster 1987:26). Lyding is onwaardig en kwaliteit van lewe word hiermee aangetas (Le Roux 1979:75; Wasserman 1976:212-213). Dit is eties beter dat iemand gehelp word om te sterf as dat hy of sy sonder rede moet ly (Fletcher 1973:670).

Voorstaanders van passiewe genadedood meen dat lewe Godgegewe is en dat dit nie wederregtelik geneem mag word nie. Al bestaan daar geen hoop op herstel nie, moet steeds alles binne die vermoë van die gesondheidsorgpersoneel gedoen word om lewe sinvol te behandel en te verpleeg. Die onttrekking van alle behandeling wat gemik is op die herstel van die lewe, beteken nie dat lewe nou sinloos geword het en dat dit nie meer die moeite werd is om te behandel nie. Sinvolle behandeling en verpleging moet geskied tot die pasiënt sterf. In hierdie verband het die pasiënt steeds die reg om met waardigheid en eerbied behandel en verpleeg te word (Douma 1979; Heyns 1986; Smit 1985; Uys \& Smit 1985; Van Vuuren \& Vorster 1987:26).

'n Verantwoordelike Christelike etiek kan geen ruimte laat vir aktiewe genadedood nie, maar wel vir passiewe genadedood. Hiermee word dus standpunt ingeneem teen die opsetlike beëindiging van 'n mens se lewe wat nie meer lewensvatbaar of sinvol beskou kan word nie. In die lig van die Christelik-etiese beginsels en norme van die Skrif moet die opsetlike beëindiging van die lewe afgewys word. Wanneer die finale en onomkeerbare sterwensproses duidelik en sonder twyfel op gang gekom het, sonder mediese hulp daartoe (die aktiewe genadedood) en deur geen menslike middel of operasie meer gekeer kan word nie, mag ook die gelowige sy of haar hande terugtrek van verdere sinlose gespesialiseerde behandeling en die sterwensproses laat voortgaan. In elk geval 
moet die liefdevolle verpleging en versorging tot die einde toe volgehou word. In hierdie gevalle gaan dit om die laaste beperkte tydsfase waarby grondige mediese advies onontbeerlik is.

Samevattend gesien, kan die volgende riglyne as eties aanvaarbaar vir passiewe genadedood beskou word:

- $\quad$ Eerbied vir die lewe moet nie verwar word met die absolute eerbied vir die lewe nie.

- Breindood is ' $n$ betroubare kriterium om vas te stel of iemand nog bioties as persoonlikheid lewe.

- Die mens is nie die produk van sy of haar lyding nie.

- Hulpverlening aan 'n terminale pasiënt mag nooit in die vorm van aktiewe genadedood wees nie.

\section{ETIESE DILEMMAS IN ABORSIE EN GENADEDOOD}

\subsection{Aborsie}

Terapeutiese aborsie is die bekendste voorbeeld van ' $n$ mediese dilemma in die mediese etiek. Binne die konteks van die Gereformeerde etiek is daar eties-aanvaarbare redes vir die beëindiging van voorgeboortelike lewe. In praktyk sluit dit ook die lewe van die moeder in as die embrio ' $n$ beter kans op oorlewing as die moeder het in gevalle waar die volhou van die swangerskap beide se lewens bedreig. Die keuse vir die behoud van die moeder se lewe word meermale gedoen op grond van die feit dat sy in 'n netwerk van verhoudings staan, byvoorbeeld 'n huwelik, 'n gesin, 'n beroep, ensovoorts. Nog 'n belangrike kriterium wat verreken moet word, is die vraag of die embrio onafhanklik van die moeder sal kan bestaan? Die keuse om die embrio te aborteer, geskied as 'n laaste uitweg om te voorkom dat meer etiese kwaad aangerig word as die neem van 'n lewe. Binne die konteks van 'n etiese lewenstyl geniet die instandhouding van die huwelik, die gesin, die beroep, ensovoorts net so 'n prioriteit as die behoud van lewe. Hierdie omstandighede sal verreken moet word wanneer 'n botsing van pligte ter sprake kom. 
Sosiaal-ekonomiese en eugenetiese indikasies vir aborsie is egter nie eties verantwoordbaar nie. Die eugenetiese indikasie lui dat net kwaliteit lewe reg op bestaan het. Twee kategorieẽ is hier ter sprake. Eerstens word hiermee bedoel dat embrio's wat na geboorte gestrem sal wees, betyds geaborteer moet word. Tweedens word met hierdie indikasie bedoel dat 'n "superras" gekweek moet word en alle embrio's wat nie aan hierdie "maatstaf" voldoen nie, ook geaborteer moet word. Terapeutiese aborsie is in die eerste kategorie van eugenese ter sprake terwyl nie-terapeutiese aborsie in die tweede kategorie ter sprake kom. Hier moet dit duidelik gestel word dat in die eerste kategorie van eugenese die graad van gestremdheid die aborsie-klassifikasie bepaal. Nie alle gestremdheid kom in aanmerking vir 'n terapeutiese aborsie nie; alleen gestremdheid wat die fetus sal verhinder om na geboorte ' $n$ sinvolle lewe te ly. Anenkefalie is ' $n$ voorbeeld hiervan. Hier is sprake van ' $n$ afwesigheid van die brein en spiraalkoord. Dit is geneties oordraagbaar en onverenigbaar met lewe en kan gedurende 'n swangerskap gediagnoseer word. Hierteenoor is iets soos klompvoete of pavalise van een/meer ledemate geen rede vir"n terapeutiese aborsie nie.

Hierdie argument beteken nie dat daar geen bestaansreg vir gestremdheid is nie. Niemand sal tog beweer dat dit vir iemand met 'n ekstra vinger of swak gesigvermoë beter sou gewees het indien hy of sy nie sou gelewe het nie. Vir hoeṿeel ouers verskaf 'n Down-sindroom kind nie vreugde nie? Maar vir die waterhofie is dit ' $n$ onreg om aan die lewe gehou te word. Dit is ' $n$ euwel om hulle van hulle lewe te beroof, maar dit is ' $n$ veel groter euwel om hulle te beskerm vir 'n lewe waaraan hulle in elk geval nie deel sal hê nie. Eerder die skuld om hulle as fetusse te aborteer as wat hulle later geëutaneer moet word.

Hierdie standpunt sal nie orals aanvaarbaar wees nie. Uys \& Smit (1985:24-25) meen dat dit in hierdie soort argument nie gaan oor die keuse tussen twee lewens nie, maar dit gaan oor die afkeuring van 'n lewe wat nie goed genoeg is nie. Die fetus word geaborteer omdat dit nie aan sekere standaarde voldoen nie. Om 'n fetus te aborteer omdat dit geestesvertraagd is, plaas 'n swaard oor die kop van alle vertraagdes. Die rasionaal agter die eugenetiese indikasie is die kwaliteit van lewe wat hulle as "heeltemal te relativisties" beskou. Hiermee keur Uys en Smit nie noodwendig aborsie in geval van swaar gestremdheid af nie. Die maatstaf hier behoort die uniekheid van elke situasie te 
wees. Omdat die mediese wetenskap betrokke by die stryd teen die gebrokenheid en versteuring van die skepping is, is aborsie by geleentheid wel toelaatbaar om sinlose lyding by die ouers en die baba te voorkom.

As standpunt kan gestel word dat in geval van swaar en onherstelbare gestremdheid 'n terapeutiese aborsie die mindere euwel is. Hiermee word standpunt ingeneem teen ander vorme van gestremdheid wat nie noodwendig die sinvolheid van die fetus se lewe sal bedreig nie. Aborsie ter wille van 'n superras is afkeurenswaardig en 'n meestervoorbeeld van die humanisties-antropologiese kategoriez van produktiwiteit en kwaliteit van lewe.

Aborsie is ook nie aanvaarbaar in geval van mislukte kontrasepsie nie. 'n Vrou kan swanger raak ten spyte van die gebruik van chemiese en meganiese kontraseptiewe middels soos die Pil, vaginale spermdoders, kondome, ensovoorts. Gerieflikheidshalwe word aborsie dan in stede van bogenoemde middels heel dikwels as geboortebeperkende middel aangewend. Hiermee het aborsie die "nuwe" Pil geword! Die probleem met hierdie vorm van "kontrasepsie" is dat dit 'n lewe vernietig wat reeds besig is om te ontwikkel in teenstelling met die bedoeling van kontrasepsie, naamlik om die ontwikkeling van 'n nuwe lewe te voorkom. Dieselfde moet gesê word van kontrasepsiemiddels soos die intra-uteriene-apparaat wat nie konsepsie voorkom nie maar inplanting. Logies gesproke is dit 'n aborsie-middel. Nog voorbeelde hiervan is die sogenaamde "superpil" en "oggend-daarna-pil". Omdat daar sprake is van 'n mens vanaf die oomblik van konsepsie, moet hierdie vorms van kontrasepsie eties afgekeur word. Die aandrang op 'n aborsie in sulke situasies kan ook nie eties regverdig word nie. Hier bots die keuse vir lewe nie met die keuse vir suksesvolle kontrasepsie nie. Trouens, geen kontrasepsie staan bekend vir die $100 \%$ betroubaarheid daarvan nie. Wie kontrasepsie gebruik, doen dit met die wete dat ook hierdie middel kan misluk en dan is daar 'n nuwe lewe verwek. Soos dit 'n etiese plig is om sinvolle gesinsbeplanning toe te pas, so is dit ook 'n etiese plig om die risiko verbonde daaraan te aanvaar. God kan myns insiens ook defekte kontrasepsie gebruik om 'n nuwe lewe te verwek. Sulke situasies moet binne die wil van God verreken word. As daar nie mediese en juridiese redes is om 'n embrio te aborteer wat as gevolg van defektiewe kontrasepsie verwek is nie, mag die embrio nie vernietig word nie. Wie dit wel doen, doen dit om geen ander rede as gerief en selfsug nie. 
Eksperimentering op embrio's is 'n kontensieuse vraagstuk in reproduktiewe sorg. Dikwels word gevra waarom geaborteerde fetusweefsel nie vir oorplanting gebruik mag word nie? Waarom mag nie op geaborteerde embrio's geëksperimenteer word nie? In die lig van argumente in hierdie artikel kan die volgende standpunt ingeneem word: Indien 'n geabörteerde fetus se weefsel met sukses gebruik kan word, is dit eties geregverdig. In die eerste plek is die aborsie nie aangevra net om die weefsel te bekom nie. Eties gesien kan die weefselmateriaal van 'n geaborteerde fetus wel gebruik word in gevalle waar dit die lewe of dan 'n kwaliteitsverbetering hiervan in bereik van iemand anders kan bring. Indien weefsel benodig word en 'n aborsie word hiervoor versoek, dan kan dit nie eties gebillik word nie. Niemand het eties die reg om 'n aborsie te versoek om 'n derde persoon te help nie.

Oorskot embrio's as gevolg van fertiliteitsbehandeling "kwalifiseer" alleen hiervoor indien hulle 'n natuurlike dood gesterf het. 'n Mens mag dus nie embrio's "kweek" met die oog op navorsing nie. Nog minder mag mens 'n embrio net laat sterf om daarop navorsing te doen. Wie dit doen, maak hom of haarself skuldig aan die onverantwoordelike verwekking van, omgang met en hantering van lewe.

Navorsing op embrio's moet binne die geformuleerde riglyne vir mediese navorsing geskied. Hier word gedink aan die noodsaaklikheid van die navorsing, die gesindheid van die navorser, die duursaamheid van navorsing, ensovoorts. Twee euwels is hier op die spel: Navorsing op geaborteerde fetusse en die weerhouding van moontlike behandeling. Die mindere euwel is om navorsing op geaborteerde fetusse te doen. Wie navorsing doen met die uitsluitlike motief om lyding te bekamp en kwalitiet van lewe te verbeter omdat die gebrokenheid van hierdie wêreld 'n mens hiertoe dwing, tree gehoorsaam en verantwoordelik in hierdie grenssituasie op. Die keuse tussen die mindere van twee euwels is juis 'n bewys dat in die situasie teen die gebrokenheid van die wêreld geprotesteer word!

'n Standpunt wat tans hoë aansien in Suid-Afrika geniet, is dat elke vrou die reg het om oor haar swangerskap te besluit. Dit hang saam met die "demokratisering van vroue", die sogenaamde empowerment of women. Die probleem met hierdie argument is dat lewe nie 'n objek is waarvan die mens willekeurig afstand van kan doen nie. 'n Mens se lewe is so nou geïntegreer met sy of haar persoonwees dat die een nie sonder die ander 
gedink kan word nie. Die demokratisering van vroue moet juis hulle reg versterk om hulle lewe en die van hulle ongebore kinders te beskerm en nie te vernietig nie.

\subsection{Genadedood}

Die opmerking is reeds gemaak dat aktiewe genadedood eties onaanvaarbaar is maar dat passiewe genadedood eties gebillik kan word. Geen mens mag van sy of haar lewe beroof word nie. Mediese ingrepe gemik op dịe beëindiging van die mens se lewe druis teen alle mediese kodes in en onteer dit as ' $n$ beroep wat homself uitgee vir die bevordering van kwaliteit lewe asook die behoud en respek van hierdie lewe. Passiewe genadedood is net eties toelaatbaar as daar geen hoop op herstel meer is nie. Trouens, passiewe genadedood word wyd algemeen gepraktiseer, sonder dat die kollig daarop val. Hier kan spesifiek verwys word na geriatriese pasiënte van wie hoë risiko-behandeling dikwels weerhou word omdat hulle lewenskwaliteit net nie van so 'n aard is dat enige mediese ingrepe (sekere medikasie uitgesluit) 'n verskil op hulle algemene gesondheids-toestand kan maak nie. In hierdie situasies word palliatiewe sorg gehandhaaf. Hierdie situasie kan eties gebillik word. Dit is 'n groter euwel om duur behandeling aan iemand te gee aan wie se lewenskwaliteit dit geen (noemenswaardige) verskil sal maak nie as om die behandeling van die pasiënt te weerhou. In multi-dissiplinêre eenhede beloop behandeling daagliks etlike duisende rande. Voeg hierby dat daar slegs beperkte bedruimte beskikbaar is en 'n situasie ontstaan waar gelyktydig gekies moet word tussen die behandeling van twee pasiënte wie se prognose dieselfde is, maar die een persoon is geriatries en die ander jonk. Hiermee word nie beweer dat lewenskwaliteit of ouderdom die deurslag moet gee nie, maar binne bogenoemde situasie kan die feite daarvan nie geïgnoreer word nie. Soos in die aborsiegeval waar verhoudings 'n woord meespreek in die keuse wat gemaak moet word, so sal verhoudings ook hier nie misgekyk kan word nie. Dit beteken egter nie dat verhoudings tot 'n ekslusiewe status verhef word nie. Die bejaarde persoon kan steeds getroud en die komateuse vrou dalk jonk wees. Sal iemand beweer dat sy behandeling geweier moet word net omdat sy nie in 'n huweliksverhouding staan of 'n gesin het nie? Nee, hier sal sake ter sprake kom soos op Wie word die geld die beste spandeer?, Wie het die grootste potensiaal om te herstel? Dit is tog voor die hand liggend dat die bejaarde persoon met ' $n$ hartarres eerder behandel sal word as die onom- 
keerbare komatieuse jong man - indien behandeling net vir een beskikbaar sou wees. Wanneer daar net een bed in die multi-dissiplinêre eenheid beskikbaar is en 'n keuse tussen die president en 'n onderwyser gemaak moet word, dan kan die amp van die president nie alleen verreken word wanneer oor behandeling besluit moet word nie. Die prognose sal (in teorie) 'n belangrike rigtinggewer wees. Prakties gesien, sal die aandrang eerder wees dat die president behandel moet word. Indien die situasie daarop wys dat dit ' $n$ mindere euwel is om die behandeling aan die president te gee as aan die onderwyser, kan dit eties gebillik word. Maar as die onderwyser 'n beter prognose as die president het, maar laasgenoemde se amp was die enigste maatstaf, dan kan hier nie sprake van etiese billikheid wees nie omdat die weerhouding van die president se behandeling nie ' $n$ groter euwel is nie. In feite is gekies vir die meerdere euwel en dit is beslis nie eties verdedigbaar nie. In 'n situasie waar 'n eweredige kans op behandeling bestaan, maar net een bed is beskikbaar, word gekies vir die president se lewe vanweë die amp wat hy of sy beklee.

Nog ' $n$ probleem in die debat oor genadedood is die vraag of behandeling geweier mag word. In 'n situasie waar behandeling sal ly tot die onnodige uitrekking van lyding en dat die volhou van die behandeling medies gesproke nie die kwaliteit van die pasiënt se lewe kan verbeter nie, is dit ' $n$ mindere euwel om behandeling te weier - van die dokter en/of die pasiënt se kant - in vergelyking met die volhou van die behandeling wat sinloos blyk te wees. In geval van ' $n$ terminale pasiënt wat aktiewe genadedood versoek, is die weiering hiertoe ' $n$ mindere euwel in vergelyking met die lewe wat van die pasiënt geneem word.

\section{PASTORAAL-ETIESE RIGLYNE VIR DIE BEËINDIGING VAN LEWE IN 'N GRENSSITUASIE}

Op sterkte van die argumente tot dusver oor die mediese beëindiging van lewe, kan die volgende riglyne geformuleer word:

Aborsie en genadedood konfronteer die Christen met die bekende vraag van sonde, siekte en lyding en God se betrokkenheid hierby. Binne die konteks van hierdie opmerking kan verskeie grondstrukture van die pastorale etiek gebruik word om mediese dilemmas te hanteer. 
Providentia Dei: Die probleem van siekte en lyding lei terug na die vraag waar die kwaad vandaan kom - dus die teodiscevraagstuk. Teodisee - in hierdie studie - word verstaan as 'n rasionele poging om die wese van God teenoor die kwaad te regverdig. Hier word gevra op watter manier God by die oorsprong, instandhouding en beteueling van die sonde teenwoordig is.

Louw (1985:21-36) onderskei tussen 'n inskakelingsteodisee (God wil die kwaad) en 'n uitskakelingsteodisee (God wil nie die kwaad nie). Nie een van hierdie benaderings bied ' $n$ oplossing vir die probleem nie. Wie sê dat God die kwaad wil, is terug by 'n Marcionistiese Godsbeeld. God moet al die skuld vir die kwaad in hierdie wêreld dra. God se teenwoordigheid word 'n angstige ervaring! Redeneer 'n mens dat God die kwaad nie wil nie, word gevra waarom laat God dit dan toe?

Die beste antwoord wat ' $n$ mens op die Teodiseeprobleem kan gee, is om te sê dat die mens ontvang van God 'n selfstandigheid maar ook die moontlikheid om dit te misbruik. Daarom het sonde altyd 'n antropologiese wortel (Pannenberg 1977:90; sien ook Zimmerli 1987:169). Eksegeties gesien, hou die Bybel die mens alleen vir die sonde verantwoordelik. Die slang word byna "toevallig" in die tuinverhaal genoem. Die rasionaal hieragter is dat die kwaad nie as 'n mag van buite verstaan moet word wat die mens tot sonde verlei het nie (Von Rad 1972:87). Die mens het immers die vryheid van keuse ontvang: Hy kon vir/teen God kies.

In die verband maak König (1991:112) 'n belangrike opmerking oor die vryheid van die mens. Hy meen dat die mens nie vrygemaak is en tegelyk verbied word om God te haat nie. Dit is tog teenstrydig. Vryheid kan tog nie beperkinge hê nie. Die mens is vrygemaak van die mag van die sonde, met ander woorde vry om vir God te kies. Hierdie vryheid is nie iets in sigself nie. Die mens besit dit nie as 'n eienskap nie. Dit is 'n verhouding. Die mens is geskape in verbond met God en in hierdie verhouding is hy of sy vry. Die vryheid wat hy of sy van God ontvang het, sluit 'n vrye keuse tussen twee moontlikhede uit. Net in verbondenheid met God kan hy of sy in vryheid leef. Elke ander moontlikheid is eintlik onmoontlik kragtens die aard en inhoud van egte vryheid. Dit is binne hierdie konteks dat die verbondsleer sinvol betrek kan word.

Op die keper beskou, kan die teodisee as teorie of verklaringsmodel nie daarin slaag om die mens te vertroos nie. Met hierdie vraagstuk word 'n rasionele spanning 
tussen God se almag en God se liefde gemaak. Die mens staan derhalwe voor die erkenning dat die oorsprong van die kwaad prinsipieel onverklaarbaar is. 'n Uitweg uit hierdie geen antwoord situasie, is om in plaas van teodisee ems te maak met die Middelaarslyding van Christus (Christologie) en die inwoning van God via God se Heilige Gees (Pneumatologie) (Louw 1985:31-33)

Die sondeleer moet ook hier benut word. Wanneer God en siekte ter sprake kom, is dit opvallend hoedat mense ' $n$ bepaalde siekte na 'n bepaalde sonde wil terugherlei. Hiermee word 'n direkte verband - oorsaak-gevolg - tussen siekte en sonde gelê. In die Ou Testament val dit op dat Job se vriende sy lyding vanuit 'n rasioneel ontwerpte Godsidee van oorsaak-gevolg wil verklaar (Job 4:8; 8:11). In die Nuwe Testament word dieselfde redenasie teruggevind in die verhaal van die blindgebore man (Joh 9:3). Hiermee word nie gesê dat daar nie 'n verband tussen sonde en siekte bestaan nie (Ps 38:3-5; 41:5) (Louw 1988:76). Trouens siekte kan 'n mens juis herinner aan die gebrokenheid van die menslike bestaan (Louw 1986:68-69; Pretorius 1984:26). Hier moet 'n duidelike onderskeid gehandhaaf word tussen siekte as gevolg van sonde en 'n direkte lyn tussen sonde en siekte. Siekte behoort nie in terme van 'n vergeldingsdogma verstaan te word nie. Die Bybel is vol voorbeelde van sondaars wat voorspoedig is (Ps 73) en regverdiges wat ly (Job). Siekte moet ook nie as destruktiewe toom gesien word nie, maar as korrigerende liefde. Onder geen omstandighede behoort ' $n$ mens siekte as destruktiewe ervaring te beskou nie. 'n Oorsaak-gevolg verband tussen sonde en siekte is eweneens onaanvaarbaar. Louw (1981:174) verwys na so 'n teologiese konstruksie as "vroom-ateïsme." Dit berus op gedrag en beloning. Godsdiens word beoefen omdat God deur die regte gedrag "gepaai" kan word en die mens sodoende voordeel daaruit kan trek.

Siekte durf nie gekwalifiseer word as 'n versteuring in een (of meer) liggaamstrukture nie. Om te sê my kop is seer, is maar net 'n simptoom van 'n geïntegreerde liggaam wat versteur is. Die aksent hier word gelê op 'n totale mens wat lyding ervaar (Smit 1988:15; Louw 1982:41; Tillich 1987:162-164). In die Bybel val dit dan ook op dat Christus die mens en nie brokstukke van 'n mens genees het nie. 'n Holistiese antropologie kom hier ter sprake.

Wanneer die Bybel oor sonde handel, konsentreer dit eerder op 'n verhoudingsprobleem, naamlik die versteuring van die verhouding tussen God en mens (Prinsloo 
1982:18 en verder; Von Rad 1975:275). König (1991:138-140) koppel dit spesifiek aan die feit dat die mens ' $n$ verhoudingswese is. Derhalwe raak die sonde al die verhoudings waarin die mens staan. Die gesindheid word deurgaans bely dat net God kan genees (2 Konings 5:7; Von Rad 1975:274). Genesing gaan dan ook dikwels gepaard met 'n vorm van sondevergifnis (Markus 2:5). God stuur direkte of indirekte genesing (Prinsloo 1982: 22). Die Nuwe Testament verwys na Christus as Geneesheer. Sy nederigheid as kneg van die Here vind ondermeer uitdrukking in sy gesagvolle optrede teenoor siekte.

Wesentlik kan dus twee standpunte oor die verband tussen sonde en siekte onderskei word. In die Ou Testament is daar 'n meer oorsaaklike verband waarvolgens siekte ' $n$ straf op sonde is. In die Nuwe Testament is daar ' $n$ wesensverband waarvolgens siekte deel is van 'n groter geheel van aanslae van Satan op die skepping: Sonde, siekte, ellende, dood (König 1991:226-228).

Daar kan geen twyfel bestaan nie dat God ook by die mens se siekte teenwoordig is. Veral die wyse waarop God hierby betrokke is, is belangrik vir die verstaan van siekte. Die beskouing dat siekte 'n straf van die Here is of dat dit 'n manier is om die mens nader na God te bring, het albei die bedoeling om die mens na die Here terug te bring (König 1991:216). God is in God se genade en toom by die sonde betrokke met die oog op die behoud en redding (heil) van die sondaar. Die mens is in sy of haar verantwoordelikheid betrokke in die hantering van sy of haar keusevryheid. Die bose is by die sonde betrokke in die verleiding van die mens ten einde binne die verbondsverhouding ' $n$ breuk tussen God en mens te slaan. Die bose is daardie duistere mag wat op diaboliese wyse God en die mens van mekaar wil vervreem. Deur middel van opstand, haat, leuentaal, ongeloof en hoogmoed slinger hy of sy die verbondsverhouding uitmekaar en skep hy of sy isolasie en chaos (Louw 1988:76). Hierdie belydenis is terapeuties in die sin dat God die sonde op veral drie wyses hanteer. God begrens die sonde deur daaraan 'n beperking te stel. Hy bestraf die sonde deur of die straf uit die bose daad self te laat voortvloei of die straf van buite af op te lê. Die sonde word benut deur die kwaad in die realisering van God se plan in te skakel. Die kwaad word nie goed gemaak nie, maar in diens van die goeie opgeneem (Heyns 1978:153-155). God regeer ook oor die kwaad en maak dit, teen die bedoeling daarvan in, diensbaar aan God se eie plan en geregtigheid (Jonker 1982:20). 
Siekte kan nooit geïsoleerd van sonde beskou word nie. Alle onvermydelike lyding is sinvol omdat Christus die lyding van 'n mens vooraf gegaan het en God se betrokkenheid via sy Heilige Gees aan hom 'n eskatologiese uitsig op die toekoms bied. God wil die lyding net in soverre as wat lyding en kwaad met God se toom en gerig in verband staan en God die lyding/kwaad dienstig maak aan God se heilswil. God kan ondanks lyding, nogtans God se genade handhaaf. Dat God die lyding nie wil nie, word nie net in sy medelye en patos met die lydende mens gedemonstreer nie, maar ook in God se "gekweste liefde". Hierdie toorn word konkreet gedemonstreer in die aard van die verbondsooreenkoms tussen God en God se volk asook in die plaasvervangende lyding van Christus die Middelaar. God se lyding is eksklusief verbondslyding en Middelaarslyding (Louw 1985:32). So gesien, moet die mense in hulle lyding protesteer teen 'n gebroke en 'n sondige wêreld waaraan hulle deel het (protesmotief). Maar by protes kan dit nie bly nie. Elkeen moet ook berusting vind in sy of haar situasie (berustingsmotief).

Naas die pastoraal-etiese grondstrukture in die probleem van siekte en lyding binne die konteks van aborsie en genadedood hierbo genoem, kan ook die volgende vermeld word:

Eskatologie en Christologie: Genadedood moet binne Bybelse perspektief benader word. As 'n mens se lewe in die hand van God is, sal na die versadiging van die lewe ook die sin van die sterwe ervaar word. Die enigste genade dood wat die Bybel ken, is om in Christus te sterf. Hierdie dood is in die ware sin van die woord 'n sagte, milde en waardige dood. Dit is tegelyk ook 'n genadige dood. Die genadedood in en deur Christus staan teenoor die lewensberowing deur die mens (Heyns 1986:335; Smit 1985:217; Velema 1980:43).

Die ouers wat die keuse vir ' $n$ aborsie en die naasbestaandes vir genadedood moet maak, worstel met die vraag van Waarom? Die Daarom! geskied dikwels in die vorm van 'n eskatologiese troos: Eendag sal begryp word waarom dit gebeur het/eendag sal geliefdes weer verenig wees/die lyding wat nou verduur word, weeg nie op teen die heerlikheid van eendag nie, ensovoorts. Hiermee word vanuit 'n eskatologiese perspektief geredeneer. Hoewel hierdie perspektief die werklikheid van die eskatologiese realisme uitwys, bring dit nie die gelowige tot ' $n$ antwoord in sy of haar situasie nie. Die korrekte perspektief sal eerder wees om hom/haar in sy of haar situasie 'n antwoord te 
gee, as om vanuit die huidige situasie na 'n ander situasie (eendag) "te spring" en dit as oplossing te beskou. Die antwoord in die huidige situasie noodsaak by geleentheid om te erken dat daar nie (altyd) rasioneel verklaarbare antwoorde is nie. Dit is hier waar die grenssituasie in die geloof aanvaar moet word - die aanvaarding dat die God nie buite hierdie situasie aanwesig is nie (Providentia Dei).

Mensbeskouing: Vanweë die intieme vervlegting van die mensbeeld met die etiese probleme van aborsie en genadedood, is dit verstaanbaar waarom die grondstruktuur so baie in hierdie paragraaf funksioneer. Minstens vier voorbeelde kan nog genoem word.

Aborsie en genadedood sal altyd 'n etiese probleem wees waarin 'n mens se geloofsoortuiging ' $n$ harde woord meespreek. Vir die Christen is God reeds voor geboorte by die lewe van die mens betrokke (Job 10:8-12; Psalm 139:13-16). God is ook die een wat wil dat nuwe lewe gevorm word (Rut 4:13) of dit nie toelaat nie (Genesis 30:2). Die Bybel gebied ook die beskerming van alle lewe (Eksodus 20:13). Verder verbied die Bybel nie net die doodmaak van lewe nie, maar gebied in die plek daarvan die verwekkking van nuwe lewe (Genesis 9:5, 7).

Die verhoudings waarin 'n mens staan, soos die huweliks-, gesin- of werksrelasie, sal 'n belangrike woord meespreek in die bepaling van die mindere euwel. Hiermee word die uitsig op die beeldskap van die mens, die eis van die sesde gebod, ensovoorts nie verduister nie, maar eerder in 'n vennootskap geplaas. Die betekenis wat verhoudings vir die bepaling van die mindere euwel het, kan hiermee nie onderskat word nie.

Hoewel die behoud van die lewe nie gemeet kan word in terme van die kwaliteit daarvan nie en ook nie afhanklik van potensiaal en ekonomiese dryfkragte is nie, kan hierdie en soortgelyke faktore nie geignoreer word wanneer 'n keuse tussen twee euwels gemaak word nie. In 'n veranderende gesondheidsorgplan waar die klem toenemend op primêre gesondheid val, is mediese geriewe en behandeling nie meer so vrylik beskikbaar as in die verlede nie.

Die vraag word dikwels geopper of iemand die reg het om die dood aan te vra? Uit die analise van die sesde gebod het dit duidelik geword dat lewe enersyds 'n gawe uit die hand van God is en andersyds dat 'n mens 'n reg en 'n verpligting het om daardie lewe te beskerm. Wie hierdie lewe onregmatig neem, tree lewensveragtend op en 
vernietig ' $n$ beelddraer van God. Die aard van die sesde gebod laat nie ruimte dat iemand die reg het om die dood aan te vra nie. Om dit nader toe te lig, onderskei Strauss $(1975: 1021 ; 1976: 135 ; 1989: 59)$ tussen subjektiewe regte en regsbelange. Die onderskeidende kenmerk van 'n subjektiewe reg is gegee in die relasie daarvan tot ' $n$ regsobjek waaroor ' $n$ feitelike genots- en beskikkingsbevoegdheid bestaan en wat ook die kompetensie tot afstand van die regsobjek impliseer. Omdat menslike lewe juis tot die mens se volle subjektiwiteit behoort, kan dit nooit tot 'n regsobjek geobjektiveer word nie en kan hy of sy ook nooit daarvan afstand doen soos daar van 'n regsobjek afstand gedoen word nie. Elke burger van die staat het 'n subjektiewe regsbelang by sy of haar lewe (staatregtelik gewaardeer as 'n publieke regsbelang). Dit beteken dat elke persoon daarby belang het dat sy of haar liggaamlike integriteit (lewe) beskerm sal word. 'n Subjektiewe regsbelang mag nie vereenselwig word met 'n vermeende subjektiewe reg wat elke mens op sy of haar lewe sou hê nie. Hiervolgens het geen mens die reg om sy of haar dood aan te vra nie.

\section{GEVOLGTREKKING}

Hoewel aborsie en genadedood van die oudste probleme in die mediese etiek is, is dit tegelyk ook van die mees kontroversiële probleme in hierdie genre van die etiek. Aborsie en genadedood konfronteer die Christen met die vraag of een mens die reg het om te besluit oor die lewe van 'n ander. Aborsie op aanvraag en aktiewe genadedood is eties afkeurenswaardig. Hier is immers ook geen sprake van 'n onafwendbare keuse of noodwendigheid nie. In die geval van terapeutiese aborsie en passiewe genadedood is daar egter ' $n$ uitsondering omdat die onafwendbaarheid van die situasie noodsaak dat 'n keuse geneem word. Dit is in hierdie situasies waar pligte teen mekaar aanloop en 'n keuse noodwendig tussen een van twee pligte gemaak moet word.

\section{Literatuurverwysings}

De Villiers D W \& Anthonissen J A S (reds) 1982. Dominee en Dokter by die siekbed. Kaapstad: NG Kerkuitgewers.

Douma J 1979. Euthanasie. Groningen: De Vuurbraak. 
Douma J 1983. Verantwoord handelen. Kampen: Uitgeverij Van den Berg.

- 1986. De Tien Geboden, II. Kampen: Uitgeverij Van den Berg.

Du Toit D A 1978. Die Christen en Aborsie. Pretoria: NG Kerkboekhandel.

- 1989. Antropologie en embriologie, in Theron \& Kinghom 1989. $101-111$.

Fletcher J 1976. Situation ethics. London: SCM.

Heyns J A 1978. Dogmatiek. Pretoria. NGKB.

- 1982. Teologiese etiek, 1. Pretoria: NG Kerkboekhandel.

- 1986. Teologiese etiek, 2/1. Pretoria: NG Kerkboekhandel.

Jonker W D 1982. Enkele opmerkings oor die probleem: God en siekte, in De Villiers \& Anthonissen 1982. 12-27.

König A 1991. Bondgenoot en beeld: Oor die wese van die mens en sonde, in Gelowig nagedink. Deel 4. (Hersiene uitgawe). Pretoria: NG Kerkboekhandel.

Lammers S E \& Verhey A (eds) 1987. On moral medicine: Theological perspectives in medical ethics. Grand Rapids: Eerdmans.

Le Roux W P 1979. Aspekte van eutanasie in die Strafreg. De Jure. 12 (2): 252-263.

Louw D J 1981. Hóópvolle perspektiewe vir die pastoraat aan die lydende vanuit die boek Job, in Odendaal (eindred) 1981: 172-183.

- 1982. Pastoraat en lyding: Teologie Aktueel 1. Kaapstad: NG Kerkuitgewers.

- 1984. Pastoraat in eskatologiese perspektief. Teologie Aktueel 3. Kaapstad: NG Kerkuitgewers.

- 1985. Sin in lyding. Kaapstad: NG Kerkuitgewers.

- 1986. Kunsmatige skenkersaadinseminasie (KIS) as teologiese vraagstuk binne die konteks van hedendaagse voortplantingstegnologie. Tydskrif vir Geesteswetenskappe. 26(1), 25-45.

- 1988. Vigs, die radikale siekte met die radikale uitdaging aan die pastorale bediening. NGTT 29 (1): 66-79.

Odendaal D H (eindred) 1981. Die Ou Testament vandag. Kaapstad: NG Kerkuitgewers. Pannenberg W 1977. Der Gott und Geschichte. Kerugma und Dogma, 23(2), 76-92.

Pretorius W W 1984. Die aspek van sinduiding in die pastorale gesprek. M Th-verhandeling. Universiteit van die Oranje-Vrystaat. 
Prinsloo W S 1982. Enkele etiese riglyne uit die Ou Testament: Die houding teenoor siekte en siekes. NGTT 23(1), 18-28.

Smit J H 1985. Etos en etiek. Bloemfontein: Patmos.

- 1988. Betekenis van 'n Christelike mensbeskouing vir die gesondheidswetenskappe. Potchefstroom: PU v CHO.

Strauss D F M 1975. Die oomblik van dood. S A Mediese Tydskrif 49, 1019-1022.

- 1976. Vraagstukke rondom die lewe juridies besien - 'n bespreking van L M du Plessis se besinning oor die onderwerp. Tydskrif vir Christelike Wetenskap 12(3\& 4), 132-139.

- 1989. Die mens en sy wêreld. Bloemfontein: Tekskor BK.

Theron P F \& Kinghorn J (reds) 1989. Koninkryk, kerk en kosmos. Bloemfontein: ProChristo Publikasies.

Tillich P 1987. The meaning of health, in Lammers \& Verhey 1987:161-165.

Uys L \& Smit J H 1985. Kliniese etiek. Kenwyn: Juta.

Van Straelen H J J M 1972. Abortus, de grote beslissing. Amsterdam: Buijten \& Schipperheijn.

Van Vuuren S J E J \& Vorster J H 1987. Eutanasie - 'n Spektrum van verhoudings. Curationis 10(1\&2), 24-32.

Velema W H 1980. Rondom het levenseinde. Kampen: Kok.

- 1983. Hoe Christelijk is de Christelijke ethiek? Kampen: Kok.

Verny T 1984. Verborge lewe van die ongebore kind. Pretoria: Femina.

Von Rad G 1972. Genesis. London: SCM

- 1975. Old Testament Theology, Volume 1. London: SCM.

Wasserman H P 1976. Geneesheer en eutanasie. Die Kerkbode 18 Februarie.

Zimmerli W 1987. Old Testament Theology in outline. Edinburgh: T \& T Clark. 